\title{
Staphylococcal food poisoning and botulism
}

\author{
R. J. GILBERT \\ M.Pharm., Ph.D., Dip.Bact., M.R.C.Path. \\ Food Hygiene Laboratory, Central Public Health Laboratory, \\ Colindale Avenue, London NW9 5 HT
}

\begin{abstract}
Summary
Staphylococcal food poisoning and botulism are caused by the ingestion of food containing exotoxins. Outbreaks of both are still a problem in many countries. This paper attempts to summarize information relating to these illnesses, together with advice on how their incidence may be reduced, or better still prevented.
\end{abstract}

\section{Introduction}

It is an unfortunate fact that each year a large number of people throughout the world become ill and sometimes die because of illnesses or diseases spread by contaminated food or water. These may vary in severity from an 'upset stomach' to food poisoning and finally to the important water-, milkor food-borne infections such as tuberculosis, brucellosis, cholera and typhoid and paratyphoid fevers. Much human suffering is caused and the burden on medical and allied manpower is heavy.

Both staphylococcal food poisoning and botulism are examples of intoxication resulting from the ingestion of food containing exotoxins. Both have a high morbidity rate and for one, botulism, the mortality rate is also often high. In recent years a number of comprehensive reviews on staphylococcal food poisoning and on the staphylococcal enterotoxins have been published (Bergdoll, 1967, 1970, 1972; Casman, 1967; Angelotti, 1969; Hobbs, 1969; Minor and Marth, 1971, 1972a, b, c, d, e). Similarly much has been written on botulism, and the published proceedings of three symposia, at Cincinnati in 1964 (Lewis and Cassel, 1964), Moscow in 1966 (Ingram and Roberts, 1967), and Hawaii in 1968 (Herzberg, 1970), record much information on the epidemiology, control and laboratory diagnosis of the disease. Useful reviews include those by Gordon and Murrell (1967), Sakaguchi (1969) and Riemann (1969).

The primary aim of this paper is to summarize some of the important facts relating to outbreaks of staphylococcal food poisoning and botulism. A second aim, perhaps more important than the first, is concerned with the prevention of these illnesses.

\section{Staphylococcal food poisoning}

Staphylococcal food poisoning is an acute intoxication resulting from the ingestion of food containing the enterotoxin produced by certain strains of Staphylococcus aureus. The illness starts suddenly, 2-6 hr after eating the contaminated food. There is acute nausea, vomiting and abdominal pain often followed by diarrhoea. In severe cases prostration and dehydration occur and intravenous therapy may be necessary: there is a high morbidity rate but a low mortality rate. The illness is usually short and sharp, with full recovery in most cases within 24 $\mathrm{hr}$ even from a state of collapse. There is no fever, in fact the patient's temperature is often subnormal.

In some countries such as the U.S.A. (Brachman et al., 1973) and Hungary (Ormay, 1971) Staph. aureus is responsible for more outbreaks of food poisoning than either Salmonella or Clostridium welchii. In England and Wales, however, staphylococcal food poisoning accounts for about $2 \%$ of all reported food poisoning incidents and about $5 \%$ of the reported cases. Nevertheless since 1949, this accumulates to over 2000 separate incidents and about 18,000 cases. Many incidents, however, particularly family outbreaks and sporadic cases, are never brought to the notice of public health authorities.

Although staphylococci are widely distributed in the environment their primary habitat is the anterior nares and the skin of man and animals. Between 25 and $50 \%$ of the human population are carriers of Staph. aureus and the prevalence and importance of this fact have been reviewed by Williams (1963). Untermann (1972) has estimated that at least $15-20 \%$ of the human population are carrying enterotoxigenic staphylococci. Lesions such as boils, carbuncles and whitlows are also foci of staphylococcal infection. Animals are another source of staphylococci although relatively few 'animal' strains produce enterotoxin (Hájek and Maršálek, 1973).

A wide variety of foods have been implicated in outbreaks of staphylococcal food poisoning. Table 1 shows the food responsible for 175 outbreaks in 
England and Wales between 1962 and 1971 (Gilbert and Wieneke, 1973). Cold meats, including cured products such as ham, tongue, corned beef and pork pies, and cold poultry are the foods most frequently implicated but some outbreaks were associated with dairy products, cooked fish and seafoods, and canned vegetables such as peas. In other countries, especially those with a warm climate, ice cream, raw milk and raw milk products such as cream and cheese are responsible for many outbreaks.

TABLE 1. Foods responsible for 175 outbreaks of staphylococcal food poisoning in England and Wales (1962-1971)*

\begin{tabular}{|c|c|c|c|}
\hline $\begin{array}{c}128(73 \%) \\
\text { Meat and poultry }\end{array}$ & & $\begin{array}{c}47(27 \%) \\
\text { Other foods }\end{array}$ & \\
\hline $\begin{array}{l}\text { Ham, boiled bacon, } \\
\text { tongue, corned beef } \\
\text { and canned pork }\end{array}$ & 67 & $\begin{array}{l}\text { Trifle, cream cakes } \\
\text { and custard } \\
\text { Cheese } \\
\text { Raw milk } \\
\text { Other dairy products }\end{array}$ & $\begin{array}{r}15 \\
2 \\
1 \\
2\end{array}$ \\
\hline Cold meat and poultry & 27 & $\begin{array}{l}\text { Canned fish } \\
\text { Processed and }\end{array}$ & 6 \\
\hline $\begin{array}{l}\text { Meat pies, sausages } \\
\text { and sausage rolls }\end{array}$ & 20 & $\begin{array}{l}\text { made-up fish } \\
\text { Frozen/canned prawns }\end{array}$ & $\begin{array}{l}6 \\
5\end{array}$ \\
\hline $\begin{array}{l}\text { Reheated meat and } \\
\text { poultry }\end{array}$ & 7 & $\begin{array}{l}\text { Canned vegetables } \\
\text { e.g. peas }\end{array}$ & 7 \\
\hline Miscellaneous & 7 & Miscellaneous & 3 \\
\hline
\end{tabular}

* From Gilbert and Wieneke (1973).

The main method of contamination of cooked food by staphylococci is by handling the food, the organisms coming from the nose, the hands or from septic lesions. Storage of the food at temperatures between 10 and $45^{\circ} \mathrm{C}$ will encourage both multiplication of staphylococci and production of enterotoxin. Canned foods including meat and fish products (Report, 1962, 1963) and vegetables such as peas (Bashford, Gillespy and Tomlinson, 1960) occasionally become contaminated because leakage occurs through minute holes in the seams of cans handled while still wet with the cooling water used after sterilization.

Bacteriological evidence is essential for the confirmation of outbreaks of staphylococcal food poisoning. In most outbreaks large numbers of Staph. aureus can be isolated from suspected foods and from faecal specimens. Table 2 summarizes the plate counts of Staph. aureus in foods implicated in 53 incidents where there was good clinical and bacteriological evidence that staphylococcal food poisoning had occurred: counts varied between $1.2 \times 10^{5}$ and $9 \times 10^{9} / \mathrm{g}$. A large number of selective media such as mannitol salt agar (Chapman, 1945), Baird-Parker agar (Baird-Parker, 1962), phenolphthalein diphosphate agar containing polymyxin (Hobbs, Kendall and Gilbert, 1968) and milk agar, have been recom- mended for the isolation and enumeration of Staph. aureus. If large numbers are present then the organisms can be isolated from non-selective media such as blood agar. Irrespective of the medium used for the isolation of Staph. aureus, confirmation by tube coagulase test is essential.

TABLE 2. Counts of Staphylococcus aureus in foods from fifty-three incidents of food poisoning

\begin{tabular}{ccc}
\hline $\begin{array}{c}\text { Counts of } \\
\text { Staph. aureus/g }\end{array}$ & $\begin{array}{c}\text { No. of } \\
\text { incidents }\end{array}$ & $\begin{array}{c}\% \text { of } \\
\text { incidents }\end{array}$ \\
\hline $10^{5}-9.9 \times 10^{5}$ & 4 & 7 \\
$10^{6}-9.9 \times 10^{6}$ & 10 & 19 \\
$10^{7}-9.9 \times 10^{7}$ & 17 & 32 \\
$10^{8}-9.9 \times 10^{8}$ & 12 & 23 \\
$>10^{9}$ & 10 & 19 \\
\hline
\end{tabular}

Range $1.2 \times 10^{5}-9 \times 10^{9} / \mathrm{g}$.

Bacteriophage-typing of staphylococci implicated in outbreaks of food poisoning enables strains isolated from victims, suspected foods and suspected food handlers to be correlated. Workers in this country established that most staphylococci implicated in food poisoning were lysed by group III phages (Allison, 1949; Williams, Rippon and Dowsett, 1953; Parker and Lapage, 1957): 88 (94\%) of the 94 strains studied by Gilbert and Wieneke (1973) were lysed by group III phages and 28 of these were also lysed by one or more phages of group I. However, enterotoxin studies on staphylococci isolated from routine samples of food not associated with food poisoning outbreaks indicate that it is impossible to predict whether a particular strain belonging to phage group III is capable of producing toxin. Parker (1972) has reviewed the technique of phagetyping and the interpretation of results.

In some outbreaks a number of distinct strains of Staph. aureus can be isolated; phage-typing, antibiotic resistance patterns, pigmentation and enterotoxin production tests may be used to distinguish these. A careful examination of individual colonies is therefore important (Hobbs et al., 1973). In a recent outbreak of staphylococcal food poisoning 3 distinct strains of Staph. aureus were isolated from both the implicated food, a cream cake, and from faecal specimens from at least one patient; 2 of the strains were also isolated from vomit specimens. Two of the strains produced enterotoxin $A$ and the third, enterotoxin B.

Staphylococci have undoubtedly caused food poisoning for centuries, and outbreaks were reported by several workers in the early 1900 s. The role of staphylococci in food poisoning was rediscovered by Dack et al. (1930), who demonstrated conclusively that contamination of food with Staph. aureus could cause gastroenteritis of sudden onset because the 
organisms growing in the food secreted an exotoxin. Because the toxin affects the bowel, it was called an enterotoxin. Until fairly recently the detection of enterotoxin in culture filtrates or in food was dependent on volunteers, or monkey feeding tests or parenteral injection into kittens or cats. However, work in this country showed that the kitten test (Fulton, 1943) and the isolated rabbit gut test (Kelsey and Hobbs, 1954) could not be relied upon for determining either the presence or absence of enterotoxin in culture filtrates.

The diligence of Professor M. S. Bergdoll, Food Research Institute, University of Wisconsin, and the late Dr E. P. Casman, FDA, Washington DC, has resulted in the purification of the enterotoxins. Five enterotoxins have been identified: A (Casman, 1960), B (Bergdoll, Surgalla and Dack, 1959), C (Bergdoll, Borja and Avena, 1965), D (Casman et al., 1967) and E (Bergdoll et al., 1971); a sixth, enterotoxin F, is under investigation. Two $C$ enterotoxins from separate strains of Staph. aureus have been purified (Borja and Bergdoll, 1967; Avena and Bergdoll, 1967) and classified as $C_{1}$ and $C_{2}$ on the basis of their different iso-electric points.

The enterotoxins are single polypeptide chains which contain relatively large amounts of lysine, aspartic and glutamic acids, and tyrosine with a mol. wt. between 28,000 and 35,000 (Bergdoll, 1972). The enterotoxins are resistant to proteolytic enzymes such as papain, trypsin, chymotrypsin and rennin; they are thermostabile and can withstand boiling and even higher temperatures. Therefore, when staphylococci grow in cooked food and produce enterotoxin, a cursory heat treatment is unlikely to destroy the toxin although the organisms themselves may be killed.

Purification of the enterotoxins and the demonstration of their antigenicity have made possible the serological detection of enterotoxin in supernatants of cultures of Staph. aureus and also in foods. Several methods have been developed such as immunofluorescence, haemagglutination inhibition, reversed passive haemagglutination and latex agglutination. However, the techniques most widely used are those employing gel-diffusion, usually the slide gel doublediffusion method of Wadsworth (1957) and Crowle (1958). The Oudin single gel diffusion tube test, the Oakley double gel diffusion tube test and Ouchter- lony plates have also been used. Recently several workers have carried out solid phase radio-immunoassay techniques (Johnson et al., 1971; Collins, Metzger and Johnson, 1972; Bennett et al., 1973; Collins et al., 1973). Serological methods are more sensitive and less expensive than the feeding of monkeys or intraperitoneal injection into cats or kittens.

Enterotoxins A, B, C, D and E have all been implicated in outbreaks of staphylococcal food poisoning in the U.S.A. and in the U.K.; strains producing enterotoxin $A$ or both $A$ and $D$ are the predominant types in outbreaks in both countries (Casman et al., 1967; Gilbert and Wieneke, 1973). Table 3 shows the types of enterotoxins produced by 120 strains of Staph. aureus from separate outbreaks in this country and demonstrated by the slide gel doublediffusion method (Šimkovičová and Gilbert, 1971). One hundred and thirteen strains $(94 \%)$ produced one or more of the enterotoxins A to E. Seven strains did not produce these toxins, but culture filtrates of 5 out of 5 strains tested produced an emetic response in monkeys typical of staphylococcal food poisoning (Bergdoll, personal communication).

Although the phage-typing of cultures and enterotoxin production tests are valuable epidemiological aids in the investigation of outbreaks, the demonstration of enterotoxin in the suspected food itself is even better proof of staphylococcal involvement. Such detection is especially important if cooking or other treatment kills the organisms but leaves the thermostabile enterotoxin still active, although as yet there is little published evidence of this. Also, in some foods such as cheese, most if not all the staphylococci may have died during maturation and storage (Zehren and Zehren, 1968). The method used in this laboratory (Gilbert et al., 1972; Gilbert and Wieneke, 1973) is a slight modification of that described by Casman (1967). It can be divided into four steps: (1) separation of the enterotoxin from insoluble food constituents; (2) separation from soluble constituents using a carboxymethyl cellulose column; (3) concentration of the eluted extract to $0.2 \mathrm{ml}$; (4) examination of the extract by means of gel-diffusion. Table 4 summarizes the results for the detection of enterotoxin in foods from some outbreaks in the U.K. Although it is possible to detect as little as 1 $\mu \mathrm{g}$ of enterotoxin/100 $\mathrm{g}$ of food (equivalent to one

TABLE 3. Enterotoxin production by strains of Staphylococcus aureus from 120 food poisoning incidents

\begin{tabular}{|c|c|c|c|c|c|c|c|c|c|c|c|}
\hline \multirow{2}{*}{$\begin{array}{c}\text { No. } \\
\text { of } \\
\text { strains* }\end{array}$} & \multirow{2}{*}{$\begin{array}{l}\% \text { producing } \\
\text { enterotoxins } \\
\text { A-E }\end{array}$} & \multicolumn{10}{|c|}{$\%$ producing enterotoxin } \\
\hline & & $\mathbf{A}$ & B & $\mathrm{C}$ & D & $\mathrm{E}$ & A \& B & $A \& C$ & $A \& D$ & $C \& D$ & $C \& E$ \\
\hline 120 & 94 & 44 & 0 & $3 \cdot 3$ & $6 \cdot 7$ & $1 \cdot 7$ & $1 \cdot 7$ & $2 \cdot 5$ & 25 & $8 \cdot 3$ & 0.8 \\
\hline
\end{tabular}

* Representative strain for each food poisoning incident. 
TABLE 4. Detection of enterotoxin in foods implicated in incidents of staphyloccocal food poisoning (1969-1973)

\begin{tabular}{cccccccc}
\hline & \multirow{2}{*}{$\begin{array}{c}\text { No. of } \\
\text { incidents }\end{array}$} & $\begin{array}{c}\text { No. of foods } \\
\text { tested }\end{array}$ & $\begin{array}{c}\text { No. containing } \\
\text { detectable amounts } \\
\text { of enterotoxin }\end{array}$ & \multicolumn{5}{c}{ Enterotoxins detected } \\
\cline { 4 - 9 } & 36 & 19 & 12 & D & E & A \& B* A \& D \\
\hline 31 & 36 & & 19 & 1 & 1 & 2 \\
\hline
\end{tabular}

* The amount of enterotoxin A or A and B varied from 0.01 to $0.25 \mu \mathrm{g} / \mathrm{g}$ of food.

part in 100 million), several negative results have been obtained. Most of the food samples submitted from outbreaks weighed c. 50-60 g. However, in one incident where enterotoxin $\mathrm{A}$ was detected in the food, the sample tested weighed only $4 \mathrm{~g}$; a very large number of Staph. aureus $4 \times 10^{9} / \mathrm{g}$ were present in the food. There is still a need for a more simple and rapid technique for detecting minute amounts of enterotoxin ( $1 \mu \mathrm{g}$ or less) in food.

Table 5 shows the approximate dosage levels of enterotoxin which have caused illness in man. Inevitably there must be a wide variation in the sensitivity of different individuals to the staphylococcal enterotoxins but the evidence suggests that less than $1 \mu \mathrm{g}$ of enterotoxin may cause illness in sensitive individuals (Bergdoll, 1973).

TABLE 5. Dosage of staphylococcal enterotoxin to cause illness in man

\begin{tabular}{ccl}
\hline Enterotoxin & Amount $(\mu \mathrm{g})$ & \multicolumn{1}{c}{ Reference } \\
\hline A & $1-4^{*}$ & Casman and Bennett (1965) \\
A & 1 & Bergdoll (1969) \\
A & $1-25^{*}$ & Gilbert et al. (1972) \\
B & $20-25$ & Raj and Bergdoll (1969) \\
A, B, C & c. 10-13† & Kautter (personal \\
& & communication) \\
\hline
\end{tabular}

* Assuming that $100 \mathrm{~g}$ of contaminated food was eaten.

$\dagger$ Estimated illness dose $\left(\mathrm{ID}_{50}\right)$ for adults fed highly purified enterotoxins A, B or C, is between 0.14 and $0 \cdot 19 \mu \mathrm{g} / \mathrm{kg}$; thus, for a man weighing $70 \mathrm{~kg}$, the $I_{50}$ is $c .10-13 \mu \mathrm{g}$.

\section{Preventive measures}

The most effective means of prevention or control of staphylococcal food poisoning are as follows.

(1) Education of the food handler in matters of personal hygiene including the washing of hands. Since it is particularly difficult to free the hands of staphylococci, it is very important that cooked foods should not be handled.

(2) Food handlers with skin infections or lesions and cuts on their hands should not work in processing plants, restaurants, and food preparation areas. Small cuts must be safely covered with really occlusive dressings.

(3) Rapid and effective refrigeration of foods such as cooked meats and poultry, milk, cream, cheese and cooked seafoods. Refrigeration will prevent the multiplication of staphylococci and the production of enterotoxin in food.

(4) All milk and milk products should be pasteurized. The sale of unpasteurized milk and cream should be actively discouraged or made illegal.

(5) Shops and supermarkets should be discouraged from selling foods in cans having signs of corrosion or damage such as dents.

(6) Maintenance of standards of hygiene in processing plants, during transportation, and by distributors, retailers and consumers. This should include thorough and regular cleaning of surfaces and equipment.

One important preventive measure is concerned with reducing the initial contamination of food with staphylococci. Table 6 shows the isolation rates of Staph. aureus from cooked sliced meats on sale in shops and supermarkets and from imported, frozen, cooked, peeled prawns and shrimps. It is clear that many samples of cooked foods do contain staphylococci. These organisms are sensitive to heat and contamination of the product, usually by handling, is most likely to have occurred after cooking. In recent years occasional routine samples of food, i.e. not connected with food poisoning outbreaks, have yielded very large numbers of Staph. aureus, for example a spoilt frozen meal $10^{6} / \mathrm{g}$, cooked ham $2 \times 10^{5} / \mathrm{g}$ and imports of frozen, cooked, peeled prawns $5 \times 10^{4} / \mathrm{g}$, pâté $>10^{6} / \mathrm{g}$ and cheddar cheese $>10^{6} / \mathrm{g}$. Such results are quite unacceptable and a hazard to public health.

\section{Botulism}

Botulism is a neuroparalytic disease affecting both man and animals and is the most dangerous form of bacterial food poisoning often with a high mortality rate. It is caused by the ingestion of food containing the toxin produced by $\mathrm{Cl}$. botulinum. Botulism continues to be a problem in several countries such as the U.S.S.R. (Matveev et al., 1967), Japan (Sakaguchi, 1969), France (Sebald, 1970), the U.S.A. (Gangarosa et al., 1971) and Iran (Rouhbakhsh-Khaleghdoust, personal communication). The foods most frequently implicated include raw, smoked and fermented fish products, home-bottled vegetables, meat and fish and home-cured salted and smoked ham. 
TABLE 6. The incidence of Staphylococcus aureus in cooked sliced meats and frozen, cooked, peeled prawns and shrimps

\begin{tabular}{lcccc}
\hline \multicolumn{1}{c}{ Food } & $\begin{array}{c}\text { Survey } \\
\text { period }\end{array}$ & $\begin{array}{c}\text { No. of } \\
\text { samples } \\
\text { tested }\end{array}$ & & \multicolumn{2}{c}{ Staph. aureus present } \\
\cline { 5 - 6 } & & & & \\
\hline $\begin{array}{l}\text { Ox tongue and pork } \\
\text { luncheon meat* }\end{array}$ & $1965-1967$ & 54 & 8 & $14 \cdot 8$ \\
$\begin{array}{l}\text { Corned beef* } \\
\text { Ham* }\end{array}$ & $1965-1970$ & 40 & 1 & $2 \cdot 5$ \\
$\begin{array}{l}\text { Imported, frozen, } \\
\text { cooked, peeled prawns }\end{array}$ & $1965-1970$ & 297 & 42 & $14 \cdot 1$ \\
and shrimps & $1968-1973$ & & & \\
\hline
\end{tabular}

* Sliced samples submitted by Public Health Inspectors.

$\dagger$ Refers to plate counts of Staph. aureus 100 or $>100 / \mathrm{g}$.

The symptoms of botulism are variable but usually include disturbances of vision and difficulties in speaking and swallowing. The mucous membranes of the mouth, tongue and pharynx are usually extremely dry. Gastro-intestinal symptoms are variable and may include vomiting, slight diarrhoea followed by constipation, and abdominal distension and pain. Mental processes are clear, and fever is absent. These symptoms are followed by progressive weakness and respiratory failure. Onset of symptoms can begin within a few hours or as late as $\mathbf{8}$ days after consumption of contaminated food, but the usual time lapse is from 18 to $36 \mathrm{hr}$. After absorption into the circulatory system, the toxin of $\mathrm{Cl}$. botulinum acts in a well defined manner blocking cholinergic junctions by preventing the presynaptic release of acetylcholine which results in the failure of nerve impulses to be transmitted across nerve fibre junctions. The most important factors in the treatment and survival of patients are prompt diagnosis and early adminis- tration of antitoxin and supportive therapy. Donadio, Gangarosa and Faich (1971) have reviewed the diagnosis and treatment of botulism.

Six distinct types of $\mathrm{Cl}$. botulinum, A, B, C, D, E and $F$ are now recognized (Table 7 ) and differentiated by the serological specificity of their toxins. Types A, B, E and F are the main causes of botulism in man; types $\mathrm{C}$ and $\mathrm{D}$ are usually associated with botulism in birds and animals. $\mathrm{Cl}$. botulinum is widely distributed in nature and is frequently found in both terrestrial and marine environments. Spores of types A and B are particularly resistant to heat and survive boiling for several hours, whereas the spores of type $\mathrm{E}$ are killed after heating at $80^{\circ} \mathrm{C}$ for $30 \mathrm{~min}$. All types can produce toxin in a variety of foods even at low temperatures, e.g. down to 10 $12 \cdot 5^{\circ} \mathrm{C}$ for strains of types $\mathrm{A}$ and $\mathrm{B}$, and $3 \cdot 3-5^{\circ} \mathrm{C}$ for strains of type $E$ and $F$ and occasionally nonproteolytic strains of type $B$.

In the investigation of incidents of botulism in

TABLE 7. Main features of the different types of Clostridium botulinum

\begin{tabular}{|c|c|c|c|}
\hline Type & Species mainly affected & $\begin{array}{l}\text { Commonest vehicles of } \\
\text { intoxication }\end{array}$ & $\begin{array}{l}\text { Areas of highest } \\
\text { geographic incidence }\end{array}$ \\
\hline $\mathbf{A}$ & $\begin{array}{l}\text { Man } \\
\text { Chickens }\end{array}$ & $\begin{array}{l}\text { Home-canned vegetables and } \\
\text { fruits; meat and fish }\end{array}$ & $\begin{array}{l}\text { Western U.S.A., } \\
\text { U.S.S.R. }\end{array}$ \\
\hline B & $\begin{array}{l}\text { Man } \\
\text { Cattle } \\
\text { Horses }\end{array}$ & $\begin{array}{l}\text { Prepared meats, especially } \\
\text { pork products }\end{array}$ & $\begin{array}{l}\text { France, } \\
\text { Eastern U.S.A., } \\
\text { U.S.S.R. }\end{array}$ \\
\hline $\mathrm{C}$ & $\begin{array}{l}\text { Cattle (Midland cattle disease), } \\
\text { Horses (forage poisoning), } \\
\text { Mink }\end{array}$ & $\begin{array}{l}\text { Rotting vegetation; } \\
\text { fly larvae }\end{array}$ & $\begin{array}{l}\text { Western U.S.A., } \\
\text { South America, } \\
\text { South Africa, } \\
\text { Australia } \\
\text { U.S.A., South Africa, } \\
\text { Australia, } \\
\text { Norway }\end{array}$ \\
\hline D & Cattle (Lamziekte) & Carrion & $\begin{array}{l}\text { South Africa, } \\
\text { Australia }\end{array}$ \\
\hline E & Man & $\begin{array}{l}\text { Uncooked, fermented or lightly } \\
\text { smoked products of fish and } \\
\text { marine mammals }\end{array}$ & $\begin{array}{l}\text { Japan, U.S.A. } \\
\text { (Alaska, Great } \\
\text { Lakes region), U.S.S.R., } \\
\text { Denmark, Sweden }\end{array}$ \\
\hline$F$ & Man & $\begin{array}{l}\text { Home-made liver paste; } \\
\text { deer-jerky }\end{array}$ & $\begin{array}{l}\text { Denmark, } \\
\text { U.S.A. }\end{array}$ \\
\hline
\end{tabular}


TABLE 8. Incidence of botulism in man

\begin{tabular}{|c|c|c|c|c|c|}
\hline \multirow[b]{2}{*}{ Country } & \multirow[b]{2}{*}{ Years } & \multicolumn{3}{|c|}{ No. of reported } & \multirow[b]{2}{*}{ Reference } \\
\hline & & Incidents & Cases & Deaths & \\
\hline U.S.A.* & $\begin{array}{l}1899-1969 \\
1970-1972\end{array}$ & $\begin{array}{r}658 \\
20\end{array}$ & $\begin{array}{r}1696 \\
60\end{array}$ & $\begin{array}{r}959 \\
15\end{array}$ & $\begin{array}{l}\text { Gangarosa et al. }(1971) \\
\text { Center for Disease } \\
\text { Control }(1971,1973 a)\end{array}$ \\
\hline U.S.S.R. & $1958-1964$ & 95 & 328 & 95 & Matveev et al. (1967) \\
\hline France & $\begin{array}{l}1940-1944 \\
1956-1970 \\
\text { (Sept.) }\end{array}$ & $\begin{array}{r}500 \\
66\end{array}$ & $\begin{array}{r}1000 \\
131\end{array}$ & $\begin{array}{r}15 \\
4\end{array}$ & $\begin{array}{l}\text { Dolman (1964) } \\
\text { Sebald (1970) }\end{array}$ \\
\hline Great Britain & $1922-1973$ & 7 & 21 & 12 & Hobbs (1973) \\
\hline
\end{tabular}

* Nine cases of botulism from wound infections have been reported between 1951 and 1972 (Merson and Dowell, 1973).

man it is essential that laboratory tests on serum samples from patients and on any remaining food samples be treated as urgent. Such action is necessary to prevent further distribution or use of the suspected food and will also enable clinicians quickly to ad. minister the appropriate therapeutic antisera to patients. The method most widely used for detecting toxin is the injection of serum or extracts of the food into mice, some of which are passively immunized with polyvalent or monovalent antisera: at the same time the foods should be cultured in a cooked meat medium for the detection and isolation of the causative organism.

Table 8 summarizes the reported incidence of botulism in man in the U.S.A., the U.S.S.R., France and Great Britain. Home-processed foods accounted for at least $72 \%$ of outbreaks in the U.S.A. between 1899 and 1969: a smaller number, sixty-one (9.3\%) of the 658 outbreaks, were attributed to commercially-processed foods (Gangarosa et al., 1971). Most of the outbreaks were caused by type A or B toxins. Botulism due to type $\mathrm{E}$ was not recognized as a major problem until 1960-1963 when outbreaks traced to fish caught and smoked in the Great Lakes area were responsible for twenty-one cases and nine deaths: another outbreak in 1963, responsible for two deaths, involved canned tuna fish. Botulism continues to be important in the U.S.A. with sixty cases and fifteen deaths reported between 1970 and 1972. In 1971, one man died after eating canned vichyssoise soup, and the recall of not only the lot of underprocessed soup but all the soup manufactured by the company, plus the adverse publicity, forced the company to file for bankruptcy. There have been recalls of chicken and vegetable soup and more recently canned mushrooms. Indeed, the Food and Drug Administration announced, in September 1973, the initiation of a nation-wide visual inspection of all commercially-canned mushrooms in stock in warehouses. Laboratory tests will be conducted on all abnormal cans to find out if they are contaminated with $\mathrm{Cl}$. botulinum toxin. This inspection has been undertaken because five commercially-canned mushroom products contaminated with botulinal toxin have been recalled so far this year (Center for Disease Control, 1973b).

Home-processed fish and ham are responsible for most incidents of botulism in the U.S.S.R. (Matveev et al., 1967) and home-cured salted or smoked hams in France (Sebald, 1970; Sebald and Saimot, 1973). Botulism is rare in the U.K. (Table 9); the first and largest reported outbreak was in 1922 at Loch Maree in Scotland (Leighton, 1923) when eight people died after eating sandwiches made from wild duck paste. A few incidents have been reported since that time, the most recent by Mackay-Scollay (1958) who reported botulism in two people who consumed pickled fish prepared in Mauritius. Hobbs and Gilbert (1971) suggested that botulism is rare in this country because (1) home-canning of all foods except acid fruits is actively discouraged, (2) of continual vigilance, and the high standards and control systems used by commercial canners, and (3) we do not eat uncooked fish.

Nevertheless, there is still concern about botulism in this country. Early in 1972 the national press carried reports that routine surveillance by the British Food Manufacturing Industries Research Association had shown that there was a high incidence of low level contamination of $\mathrm{Cl}$. botulinum in

TABLE 9. Incidents of botulism in man in Great Britain*

\begin{tabular}{lclc}
\hline Year & $\begin{array}{c}\text { No. of } \\
\text { cases }\end{array}$ & \multicolumn{1}{c}{ Food vehicle } & $\begin{array}{c}\text { Cl. botulinum } \\
\text { type }\end{array}$ \\
\hline 1922 & 8 & Duck paste & A \\
1932 & 2 & Rabbit and pigeon broth & $?$ \\
1934 & 1 & Jugged hare & $?$ \\
1935 & 2 & Vegetarian nut brawn & A \\
1935 & 1 & Home-made meat pie & B \\
1949 & 5 & Macaroni cheese & $?$ \\
1955 & 2 & Pickled fish from Mauritius & A \\
\hline \multicolumn{5}{c}{ * Data from Hobbs (1973). }
\end{tabular}


trozen unsmoked trout both imported and homeproduced. Further research and discussion between interested parties continues. Frozen trout should be adequately thawed, thoroughly cooked and eaten immediately.

Recently, attention has been drawn to the importance of reconsidering the use of the curing salts sodium nitrate and sodium nitrite in certain foods such as ham, because nitrites can react with secondary and tertiary amines to form nitrosamines, and many of these are carcinogenic in laboratory animals. The permitted content of nitrates and nitrites in cured and preserved meats was restricted in this country in 1971 to a maximum of 500 parts $/ 10^{6}$ of sodium or potassium nitrate and 200 parts $/ 10^{6}$ of sodium or potassium nitrite. Large canned hams are not subjected to a 'botulinum cook' but are only pasteurized. Reliance for preservation is placed, therefore, on a number of factors including pasteurization conditions, $\mathrm{pH}$, the presence of various curing salts such as sodium chloride and sodium nitrite, and the temperature of storage. Any moves further to reduce the amount of nitrite or eliminate it entirely from cured and preserved meats must take into consideration the possible risks of botulism. In reducing a possible risk from nitrosamines we may be creating another. The dilemma of nitrites, nitrates and nitrosamines in food has been reviewed (Wolff and Wasserman, 1972; Aune, 1972).

Animal botulism is most frequently caused by types $\mathrm{C}$ and $\mathrm{D}$ although types $\mathrm{A}$ and $\mathrm{B}$ have also been implicated. Outbreaks in many countries have caused significant losses of wild and domestic animals including wild duck, rabbits, cattle, sheep, horses, mink and broiler chickens. Several outbreaks of type $\mathrm{C}$ botulism have been reported recently in Great Britain (Roberts et al., 1972) and details of these are summarized in Table 10. Outbreaks of type C botulism in broiler chickens (Blandford and Roberts, 1970; Roberts, Thomas and Gilbert, 1973) posed a particular problem because little is known about the susceptibility of man to type $\mathrm{C}$ intoxication: indeed, little is known about the sources of $\mathrm{Cl}$. botulinum type $\mathrm{C}$ and the epidemiology of the disease in animals.

There are only three reports in the literature of type $\mathrm{C}$ botulism in man from the U.S.A. (Meyer et al., 1953), France (Prévot et al., 1955) and the U.S.S.R. (Matveev et al., 1967), and only one of type D botulism (Demarchi et al., 1958). These reports are not entirely conclusive but it would be unwise to ignore the possibility that type $\mathrm{C}$ botulism might be a hazard to man. $\mathrm{Cl}$. botulinum type $\mathrm{C}$ has been detected in cavity swabs from $4(0.32 \%)$ of 1249 broiler chickens from c. 100 separate farm units in Great Britain (Report, 1971); all the chickens were believed to be derived from normal healthy stock.
TABLE 10. Recent confirmed outbreaks of type C botulism in birds and mammals in Great Britain*

\begin{tabular}{cclc}
\hline Year & $\begin{array}{c}\text { No. of } \\
\text { outbreaks }\end{array}$ & \multicolumn{1}{c}{ Species affected } & $\begin{array}{c}\text { No. of } \\
\text { deaths }\end{array}$ \\
\hline 1969 & 3 & Mainly mallard duck & $800+$ \\
& 2 & Ferret & 9 \\
1970 & 1 & Mink & c. 450 \\
& 2 & Mainly mallard duck & $140+$ \\
1971 & 4 & Broiler chicken & c. 4100 \\
& 1 & Mallard duck & 60 \\
& 2 & Waterfowl & $30+$ \\
\hline \multicolumn{3}{c}{}
\end{tabular}

\section{Preventive measures}

The spores of $\mathrm{Cl}$. botulinum are widely but irregularly scattered in the soil and off-shore water of many countries. Hence, for example, vegetables grown in these areas, or fish and marine mammals feeding in such waters, are liable to contamination by the spores. Botulism can be prevented by any of the following measures.

(1) Destruction of the spores by heat or irradiation;

(2) inhibition of growth by (a) reduction of the $\mathrm{pH}$ (b) reduction of the temperature by refrigeration or freezing (c) limitation of the water content by drying or by the addition of salt or sugar (d) addition of inhibitory substances such as sodium nitrite;

(3) inactivation of preformed toxin by cooking foods before consumption.

Preventive measures based on inhibition of growth require, like any canning process, a rigidly controlled procedure.

It is important therefore to (1) discourage the home-preservation of meat, poultry, fish and most vegetables, except by freezing; (2) discourage the consumption of raw and fermented fish products; and (3) to insist on a 'botulinum cook' for uncured canned meats, and canned soups and vegetables.

\section{Botulism from wound infections}

In conclusion, it must be mentioned that nine cases of botulism from wound infections have been reported from the U.S.A. (Merson and Dowel, 1973). The incubation period between the occurrence of the wound and the onset of neurological symptoms has been between 4 and 14 days and the epidemiology can be likened to that of tetanus, as toxin production occurs in vivo. Wound botulism should be considered as a possible cause of clinical botulism in cases where foods cannot be incriminated.

\section{Acknowledgments}

It is a pleasure to record my thanks to the many Directors of Public Health Laboratories and hospital bacteriologists for sending us cultures of Staph. aureus, samples of food and other information from incidents of staphylococcal food 
poisoning, and to my colleague Miss Antonnette A. Wieneke for providing most of the experimental data included in Tables 3 and 4 . The reference enterotoxins and antisera were kindly supplied by Professor M. S. Bergdoll, Food Research Institute, University of Wisconsin, U.S.A., and Dr R. W. Bennett, Food and Drug Administration, Washington DC, U.S.A.

\section{References}

Allison, V.D. (1949) In: Discussion on food poisoning. Proceedings of the Royal Society of Medicine, 42, 216.

ANGelotti, R. (1969) Staphylococcal intoxications. In: Foodborne Infections and Intoxications (Ed. by H. Riemann), p. 359. Academic Press: New York.

Aune, T. (1972) Nitrite, nitrosamines and cancer. Nordisk Veterinaermedicin, 24, 356.

Avena, R.M. \& Bergdoll, M.S. (1967) Purification and some physicochemical properties of enterotoxin C, Staphylococcus aureus strain 361. Biochemistry, 6, 1474.

BaIRD-PARKer, A.C. (1962) An improved diagnostic and selective medium for isolating coagulase-positive staphylococci. Journal of Applied Bacteriology, 25, 12.

BASHFord, T.E., GillesPy, T.G. \& TOMLinson, A.J.H. (1960) Staphylococcal food poisoning associated with processed peas. Fruit and Vegetable Canning and Quick Freezing Research Association, Chipping Campden, England.

Bennett, R.W., Keoseyan, S.A., Tatini, S.R., Thota, H. \& Collins, W.S. (1973) Staphylococcal enterotoxin: a comparative study of serological detection methods. Canadian Institute of Food Science and Technology Journal, 6, 131.

BERGDOLL, M.S. (1967) The staphylococcal enterotoxins. In: Biochemistry of Some Food-borne Microbial Toxins (Ed. by R. I. Mateles and G. N. Wogan), p.1. M.I.T. Press: Cambridge, Mass.

Bergdoll, M.S. (1969) Bacterial toxins in food. Food Technology, 23, 132.

Bergdoll, M.S. (1970) Enterotoxins. In: Microbial Toxins (Ed. by S. J. Ajl, T. C. Montie and S. Kadis), 3, p. 265. Academic Press: New York.

BERGDOLL, M.S. (1972) The enterotoxins. In: The Staphylococci (Ed. by J. O. Cohen), p. 301. Wiley-Interscience: New York.

Bergdoll, M.S. (1973) Enterotoxin detection. In: The Microbiological Safety of Food (Ed. by B. C. Hobbs and J. H. B. Christian), p. 287. Academic Press: London.

Bergdoll, M.S., BorJa, C.R. \& Avena, R.M. (1965) Identification of a new enterotoxin as enterotoxin $C$. Journal of Bacteriology, 90, 1481.

Bergdoll, M.S., Borja, C.R., Robbins, R. \& Weiss, K.F. (1971) Identification of enterotoxin E. Infection and Immunity, 4, 593.

Bergdoll, M.S., Surgalla, M.J. \& Dack, G.M. (1959) Staphylococcal enterotoxin. Identification of a specific precipitating antibody with enterotoxin-neutralizing property. Journal of Immunology, 83, 334.

BLANDFORD, T.B. \& ROBERTS, T.A. (1970) An outbreak of botulism in broiler chickens. Veterinary Record, 87, 258.

Borja, C.R. \& Bergdoll, M.S. (1967) Purification and partial characterization of enterotoxin $C$ produced by Staphylococcus aureus strain 137. Biochemistry, 6, 1467.

Brachman, P.S., Taylor, A., Gangarosa, E.J., Merson, M.H. \& BARKER, W.H. (1973) Food poisoning in the U.S.A. In: The Microbiological Safety of Food (Ed. by B. C. Hobbs and J. H. B. Christian), p. 143. Academic Press: London.

CASMAN, E.P. (1960) Further serological studies of staphylococcal enterotoxin. Journal of Bacteriology, 79, 849.

CASMAN, E.P. (1967) Staphylococcal food poisoning. Health Laboratory Science, 4, 199.

Casman, E.P. \& BennetT, R.W. (1965) Detection of staphylococcal enterotoxin in food. Applied Microbiology, 13, 181.
Casman, E.P., Bennett, R.W., Dorsey, A.E. \& Issa, J.A. (1967) Identification of a fourth staphylococcal enterotoxin, enterotoxin D. Journal of Bacteriology, 94, 1875.

Center for Disease Control (1971) Botulism in the United States, 1970. Morbidity and Mortality Weekly Report, 20, No. 39, 356.

Center for Disease Control (1973a) Food-borne botulism, United States 1971-1972. Morbidity and Mortality Weekly Report, 22, No. 7, 62.

Center for Disease Control (1973b) Warehouse inspection of canned mushrooms. Morbidity and Mortality Weekly Report, 22, No. 38, 324.

Chapman, G.H. (1945) The significance of sodium chloride in studies of staphylococci. Journal of Bacteriology, 50, 201.

Collins, W.S., Johnson, A.D., Met7.ger, J.F. \& Bennett, R.W. (1973) Rapid solid-phase radioimmunoassay for staphylococcal enterotoxin A. Applied Microbiology, 25, 774.

Collins, W.S., Metzger, J.F. \& Johnson, A.D. (1972) A rapid solid phase radioimmunoassay for staphylococcal B enterotoxin. Journal of Immunology, 108, 852.

Crowle, A.J. (1958) A simplified micro double-diffusion agar precipitin technique. Journal of Laboratory and Clinical Medicine, 52, 784.

Dack, G.M., Cary, W.E., Woolpert, O. \& Wiggers, H. (1930) An outbreak of food poisoning proved to be due to a yellow haemolytic staphylococcus. Journal of Preventive Medicine, 4, 167.

Demarchi, J., Mourgues, C., Orio, J. \& Prévot, A.R. (1958) Existence du botulism humain de type D. Bulletin de l'Académie Nationale de Médecine, 142, 580.

Dolman, C.E. (1964) Botulism as a world health problem In: Botulism (Ed. by K. H. Lewis and K. Cassel), p. 5 . U.S. Department of Health, Education and Welfare Cincinnati.

Donadio, J.A., Gangarosa, E.J. \& Faich, G.A. (1971) Diagnosis and treatment of botulism. Journal of Infectious Diseases, 124, 108.

Fulton, F. (1943) Staphylococcal enterotoxin with special reference to the kitten test. British Journal of Experimental Pathology, 24, 65.

Gangarosa, E.J., Donadio, J.A., Armstrong, R.W., Meyer, K.F., Brachman, P.S. \& Dowell, V.R. (1971) Botulism in the United States, 1899-1969. American Journal of Epidemiology, 93, 93.

Gilbert, R.J. \& Wieneke, A.A. (1973) Staphylococcal food poisoning with special reference to the detection of enterotoxin in food. In: The Microbiological Safety of Food (Ed. by B. C. Hobbs and J. H. B. Christian), p. 273. Academic Press: London.

Gilbert, R.J., Wieneke, A.A., LANSER, J. \& ŠImkovičová, M. (1972) Serological detection of enterotoxin in foods implicated in staphylococcal food poisoning. Journal of Hygiene, 70, 755.

Gordon, R.A. \& Murrell, W.G. (1967) Botulism, a review of the present situation. CSIRO Food Preservation Quarterly, 27, 6.

HÁJEK, V. \& MARŠÁLEK, E. (1973) The occurrence of enterotoxigenic Staphylococcus aureus strains in hosts of different animal species. Zentralblatt für Bakteriologie, Parasitenkunde, Infektionskrankheiten und Hygiene. I. Abteilung Originale $A, 223,63$.

Herzberg, M. (1970) (Ed.) Proceedings of the First U.S.Japan Conference on toxic micro-organisms-mycotoxins, botulism. U.S. Department of Interior, Washington, DC.

Hoввs, B.C. (1969) Staphylococcal and Clostridium welchii food poisoning. In: Bacterial Food Poisoning (Ed. by J. Taylor), p. 67. The Royal Society of Health: London. 
Hoввs, B.C. (1973) Food-borne diseases in relation to tourism. The problem viewed from British experience. Proceedings of the 6th International Symposium of the World Association of Veterinary Food Hygienists. Elsinore: Denmark.

Hobbs, B.C., Clifford, W., Ghosh, A.C., Gilbert, R.J., Kendall, M., Roberts, D. \& WieneKe, A.A. (1973) Sampling of food and other materials for bacteriological and ecological studies. In: Sampling-Microbiological Monitoring of Environments (Ed. by R. G. Board and D. W. Lovelock), p. 233. Society for Applied Bacteriology Technical Series Number 7. Academic Press: London.

HobBs, B.C. \& GilberT, R.J. (1971) Botulism from canned soup. Lancet, ii, 1157.

Hobbs, B.C., Kendall, M. \& Gilbert, R.J. (1968) Use of phenolphthalein diphosphate agar with polymyxin as a selective medium for the isolation and enumeration of coagulase-positive staphylococci from foods. Applied Microbiology, 16, 535.

INGRAM, M. \& RoBerTs, T.A. (1967) (Eds) Botulism, 1966. Chapman and Hall: London.

Johnson, H.J., Bukovic, J.A., Kauffmann, P.E. \& Peeler, J.T. (1971) Staphylococcal enterotoxin B: solid-phase radioimmunoassay. Applied Microbiology, 22, 837.

Kelsey, J.C. \& HobBs, B.C. (1954) Studies on the effect of staphylococcal culture filtrates on isolated rabbit gut. Journal of Hygiene, 52, 502.

Leighton, G.R. (1923) Report of the Circumstances Attending the Deaths of Eight Persons from Botulism at Loch Maree. Her Majesty's Stationery Office: Edinburgh.

LEWIS, K.H. \& CASSEL, K. (1964) (Eds) Botulism, publication No. 999-FP-1. U.S. Department of Health, Education and Welfare: Cincinnati.

Mackay-Scollay, E.M. (1958) Two cases of botulism. Journal of Pathology and Bacteriology, 75, 482.

Matveev, K.I., Nefedjeva, N.P., Bulatova, T.I. \& SokoLOV, I.S. (1967) Epidemiology of botulism in the U.S.S.R. In: Botulism, 1966 (Ed. by M. Ingram and T. A. Roberts), p. 1. Chapman and Hall: London.

Merson, M.H. \& Dowell, V.R. (1973) Epidemiologic, clinical and laboratory aspects of wound botulism. New England Journal of Medicine, 289, 1005.

Meyer, K.F., Eddie, B., York, G.K., Collier, C.P. \& TownSEND, C.T. (1953) Clostridium botulinum type C and human botulism. Proceedings of the 6th International Congress of Microbiology, p. 18. Rome.

MinOR, T.E. \& MARTH, E.H. (1971) Staphylococcus aureus and staphylococcal food intoxications. A review. I. The staphylococci: characteristics, isolation and behaviour in artificial media. Journal of Milk and Food Technology, 34, 557.

Minor, T.E. \& MARTH, E.H. (1972a, b, c) Staphylococcus aureus and staphylococcal food intoxications. A review. II. Enterotoxins and epidemiology. III. Staphylococci in dairy foods. IV. Staphylococci in meat, bakery products, and other foods. Journal of Milk and Food Technology, 35, $21 ; 77 ; 228$.

Minor, T.E. \& Marth, E.H. (1972d, e) Staphylococcal food poisoning. A review. I. Characteristics and isolation of staphylococci, properties of enterotoxins, and epidemiology of staphylococcal intoxications. II. Behaviour of staphylococci in artificial media and foods. Indian Journal of Nutrition and Dietetics, 9, 161; 225.
ORMAY, L. (1971) Some problems concerning bacteriological standards for food. Elelmezesi Ipar, 25, 74.

PARKER, M.T. (1972) Phage-typing of Staphylococcus aureus, In: Methods in Microbiology (Ed. by J. R. Norris and D. W. Robbins), 7B, 1. Academic Press: London.

Parker, M.T. \& LAPage, S.P. (1957) Penicillinase production by Staphylococcus aureus from outbreaks of food poisoning. Journal of Clinical Pathology, 10, 313.

Prévot, A.R., Terrasse, J., Daumail, J., Cavaroc, M., Riol, J. \& Sillioc, R. (1955) Existence en France du botulisme humain de type C. Bulletin de l'Académie Nationale de Médecine, 139, 355.

RAJ, H.D. \& BERGDOLL, M.S. (1969) Effect of enterotoxin B on human volunteers. Journal of Bacteriology, 98, 833.

REPORT (1962) Food poisoning in England and Wales, 1961. Monthly Bulletin of the Ministry of Health and the Public Health Laboratory Service, 21, 180.

REPORT (1963) Food poisoning in England and Wales, 1962. Monthly Bulletin of the Ministry of Health and the Public Health Laboratory Service, 22, 200.

REPORT (1971) Report on the incidence of Clostridium botulinum in dressed poultry. Veterinary Record, 89, 668.

RiemanN, H. (1969) Botulism-types A, B and F. In: Foodborne Infections and Intoxications (Ed. by H. Riemann), p. 291. Academic Press: New York.

Roberts, T.A., Keymer, I.F., Borland, E.D. \& SMith, G.R. (1972) Botulism in birds and mammals in Great Britain. Veterinary Record, 91, 11.

Roberts, T.A., Thomas, A.I. \& Gilbert, R.J. (1973) A third outbreak of type $\mathrm{C}$ botulism in broiler chickens. Veterinary Record, 92, 107.

SAKAGUCHI, G. (1969) Botulism-type E. In: Food-borne Infections and Intoxications (Ed. by H. Riemann), p. 329. Academic Press: New York.

Sebald, M. (1970) Sur le botulisme en France de 1956 à 1970. Bulletin de l'Académie Nationale de Médecine, 154, 703.

Sebald, M. \& Saimot, G. (1973) Toxémie botulique. Intérêt de sa mise en évidence dans le diagnostic du botulisme humain de type B. Annales de Microbiologie, 124A, 61 .

Šımkovičová, M. \& Gilbert, R.J. (1971) Serological detection of enterotoxin from food poisoning strains of Staphylococcus aureus. Journal of Medical Microbiology, 4, 19.

UNTERmanN, F. (1972) Contribution to the occurrence of enterotoxin producing staphylococci in man. Zentralblatt für Bakteriologie, Parasitenkunde, Infektionskrankheiten und Hygiene. I. Abteilung Originale A, 222, 18.

WADSWORTH, C. (1957) A slide microtechnique for the analysis of immune precipitates in gel. International Archives of Allergy and Applied Immunology, 10, 355.

Williams, R.E.O. (1963) Healthy carriage of Staphylococcus aureus: its prevalence and importance. Bacteriological Reviews, 27, 56.

Williams, R.E.O., Rippon, J.E. \& Dowsett, L.M. (1953) Bacteriophage typing of strains of Staphylococcus aureus from various sources. Lancet, i, 510.

WolfF, I.A. \& WASSERman, A.E. (1972) Nitrates, nitrites, and nitrosamines. Science, 177, 15.

ZeHren, V.L. \& Zehren, V.F. (1968) Examination of large quantities of cheese for staphylococcal enterotoxin $\mathrm{A}$. Journal of Dairy Science, 51, 635. 